\title{
ANALYSIS ON ECONOMICAL AND ECOLOGICAL POTENTIAL BENEFITS OF ARTIFICIAL CORAL REEFS PLANTING ACTIVITIES
}

\author{
Susilo Edi*, Purwanti Pudji, Fattah Mochammad \\ Department of Social Fishery Economy, Faculty of Fishery and Marine Sciences, \\ University of Brawijaya, Indonesia \\ *E-mail: olisuside@gmail.com
}

\begin{abstract}
Conversion activities of mangrove forest area into plantation area at Damas Beach has caused sedimentational effect on the coral reefs and the increasing ecosystem damages in the coral reefs ecosystem, which in turn will affect on the decreasing yields of fishermen. This condition has caused vulnerability to the decline of fish resources as the ecosystem has been damaged. The alternative through planting the artificial coral reefs is one way to improve the ecosystem of the damaged coral reefs. This study analyzes the economic and ecological benefits of coral reef reforestation. Based on the results of the analysis, it was obtained that the artificial coral reefs of $9 \mathrm{sq} . \mathrm{m}$. with a length of $8.3 \mathrm{~m}$ has been assumed to produce direct benefits in the form of ornamental fish production, while the indirect benefits are as living fish habitat, coastal protection and carbon sinks with the total economic value of IDR 4,580,344.18 per year.
\end{abstract}

\section{KEY WORDS}

Community behavior, business development, artificial coral reefs, Prigi gulf.

Coastal areas have interconnected main ecosystems, namely coral reef ecosystem, mangrove ecosystem and seagrass ecosystem. Prigi Gulf area in Trenggalek Regency, East Java, has several beaches that have either mangrove ecosystem or coral reef ecosystems. Damas Beach is one of the coastal area located in Karanggandu Village, Watulimo District, Trenggalek Regency, western of the Prigi Gulf. Damas Beach has mangrove forest area around Bang and Ngrumpukan estuaries. The activities of the local community are considered less responsible in terms of the use of coastal areas, causing changes in the ecosystem of marine biota on the coastal area, particularly the atcivities of the coastal communities around Damas Beach.

Based on the results of studies by Susilo et.al. (2008) and Purwanti et.al. (2015) have indicated the tendency of the activities to reduce the coverage of mangrove forest around 2 river estuaries in Damas Beach at points B and C. In addition, there is also forest cutting activities near Mount Kumbokarno area at point $D$ and land conversion in the surrounding area by planting productive trees which has caused flash floods. As the interconnectedness of mangrove ecosystems with coral reef ecosystems, and the water flowing to the sea carrying sediment and the use of tensile net at point $A$ to catch fish, it has caused damages to the coral reef ecosystems at point $E$ (Figure 1). Moreover, the mindset of local community near Karnggandu Village who consider the coral reef ecosystems are not lucrative in terms of economic value, so that the existence of coral reef ecosystems and its conservation is not the main concern for the community. Village Administration in 2009 has issued Village regulation Number 04 of 2009 on the Zoning of Coastal Area of Karanggandu Village, but the regulation has not run optimally to control the activities; there are still several misconduct of community activities that are potentially distructive to the ecosystems of mangrove forest, especially the coral reef ecosystems in the coastal area.

According to Cofish Project report in 2004, the condition of coral reefs in Ngrumpukan waters territory was categorized in serious damage. The dominant coral species are Acropora sp. with living coral coverage was about $35 \%$ of the 21 species of the coral reefs. Natural corals that grow in Ngrumpukan area, according to the research of Susilo, et.al. (2007), covered an area of $1 \mathrm{Ha}$ in the steep hills in front of Ngrumpukan beach at a depth of 
between 2 and 6 meters at the lowest ebb. There were 10 coral species that grow around the area, with coral coverage ranging from $10 \%$ to $75 \%$, and the average coral coverage was $38.38 \%$. The comparison of species of the coral reefs and their coverage between 2004 and 2007, there have been 11 species of coral reef declining, while in terms of the coverage, there has been an indication of increasing number of $3.38 \%$. The increased coral cover is assumed due to the decreased sedimentation density as the surrounding forest has been recovering as well as the lowering number of naturally-unfriendly fishing practices.

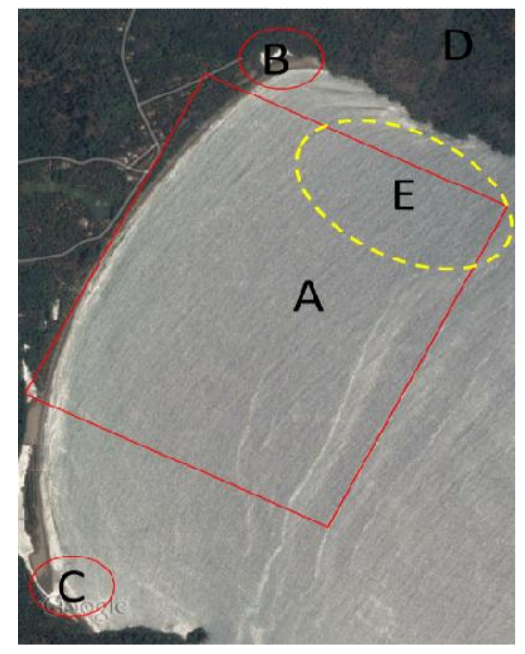

Notes:

A: fish catch area with tensile net method

B: river estuary (Ngrumpukan)

C: river estuary (Pancer Bang)

D: Mount Kumbukarno

E: coral reef ecosystems

Figure 1 - The Overview of Coastal Area near Damas Beach

Such efforts to prevent the destruction of the two coastal ecosystems, Cofish Project that has ended in 2005, has established a community which is aimed at monitoring the ecosystems (Pokmaswas) "Jangkar Bahari" on Damas Beach for the management of coastal ecosystems and mangrove forests in Pancer Ngrumpukan and Pancer Bang. In addition, the Department of Marine and Fisheries of Trenggalek Regency together with the Center for Socio-Economic Research from the Ministry of Marine and Fisheries Affairs have assigned Pokmaswas "Udang Jaya" to manage the existence of coral reefs in the Prigi Gulf region.

The damage to the coral reef ecosystems in the coastal area of Damas has been mainly caused by human behaviors such as the use of environmentally unfriendly fishing gears, and the destruction of forest ecosystems has impacts on the coral reef ecosystems. Based on the above problems, one effort proposed is the utilization of artificial coral reefs that has been planted through the cooperation of two groups of mangrove management and coral reef management called "Jangkar Bahari" group and "Udang Jaya" group. The main objective of the artificial reef planting activities is to prevent the decline of fish resources and may increase the extent of coral coverage. This study aims to (1) describe coral reef planting activities that have been implemented in Damas Beach, and (2) analyze the economic ecological benefits of the planting of artificial reefs that have been planted in Damas Beach. The results of this study are expected to be used as the reference and input for local stakeholders in the management of coral reef ecosystems in Damas Beach.

\section{METHODS OF RESEARCH}

The material of this research is the planting activities of artificial reefs on iron frame and cast concrete. The method used for this research was the active participation method that the activities of active participation were done by involving 2 groups of mangrove management groups "Jangkar Bahari" and "Udang Jaya". In addition, the activities also involved local stakeholders namely Head of Karanggandu Village as the village level stakeholder and a public figure who served as the Head of Community Council of Forest Village (LMDH) "Argo Lestari" of Karanggandu Village. There were 2525 artificial reefs planted with the dimension of the artificial coral reefs is $60 \mathrm{~cm}$ long, $60 \mathrm{~cm}$ wide and $10 \mathrm{~cm}$ 
thick. The activities of the coral reef planting cost IDR 576,000 per unit of the artificial coral reef with an overall area of $0.288 \mathrm{~m}^{3}$. The number of group members involved in the activities was 15 people.

The first objective of this research was analyzed through descriptive analysis by explaining the planting activities of the artificial reefs. For the second objective, it was conducted by using economic valuation of the planting of the artificial coral reefs both in terms of economic and ecological aspects, either direct or indirect benefits which is formulated as follows:

$$
T E V=D U V+I U V
$$

Where: TEV = Total Economic Value; DUV = Direct Use Value; IUV = Indirect Use Value.

\section{RESULTS AND DISCUSSION}

Planting activities of artificial coral reefs. The planting activities of coral reefs were initiated with negotiations with public figures and senior citizens who are domiciled in Damas and also leaders of community who utilize fishery resources in Damas Beach area. The initial negotiation was carried out in two stages. First stage was conducted with intensive two hour discussion with Head of Pokmaswas "Jangkar Bahari" dated July 17, 2017 evening between 7 to 9 p.m. at the Mr. JAT's home, with the main discussion was related to the plan of making the artificial coral reefs and working mechanism for the community. The second discussion was mainly conducted to meet the resource users in the area of Damas Beach. The discussion was easier as both of the figures joined in the local art group of Jaranan Turangga Yaksa, which was named Kumbo Karno, taken from the name of Ramayana puppetry legends, which is also used as the name of the mountain on Prigi Gulf.

Another discussion to explain the size and number of artificial coral reefs was carried out on July 18, 2017 at the art house together with Mr. DST. Residents requested from the $\mathrm{IbM}$ team to provide technical details of the artificial coral reefs. At the end of this initial negotiation would be followed up by the technical specifications of the artificial coral reefs and the way of transporting them to the middle of the sea and sinking them to the location of the expected coral reefs in Ngrumpukan. The initial negotiations of the second phase were delivered at the art house built at the border of Damas Beach.

The location of putting the artificial coral reefs on the bottom of the water was right on the natural coral reefs that have been damaged due to human activities. The first two stages of negotiation were also conducted with the head of community council. This negotiation is important to ensure the smoothness of IbM activities, and it also discussed the continuation of the development of the Citizenship Meetings in Damas area.

The second negotiation of the second phase was carried out by involving the representative of Damas residents at the community leader's house in Karanggandu. The negotiation of this phase has agreed on the technical dimensions of the artificial coral reefs with the following details presented in Table 1 . The dimensions amd material requirements have been undertaken and agreed to be done within a month.

The first two stages of negotiation were also conducted with head of communicy council. The negotiation is important to ensure the smoothness of IbM activities, and it also discussed the continuation of the development of the Citizenship Meetings in Damas.

There were two main topics for the Focus Group Discussion (FGD) with the Damas residents, namely: (a) ecological, social, and economic functions of coral reefs for life for both environment and human, and (b) the socialization of Village Regulation Number 04 of 2009. The materials for the discussion were delivered by IbM team, attended by 20 residents as well as by the Head of Karanggandu Village, Head of Gading Sub-village, and Heads of Neighbourhoods of Damas.

There are two main results from the FGD as follows: 
According to Head of Karanggandu Village, the Village Regulation Number 04 of 2009 needs revision considering the inventions and development of management systems for coastal resources; and

Residents questioned the supervision mechanism towards the artificial coral reefs planted in the waters to ensure the preservation and continuity of the artificial coral reefs. As the existence of two groups of "Jangkar Bahari" and "Udang Jaya" in Damas area, and both have been directly involved in the procurement process of goods as well as the planting activities, the supervision was decided to be assigned to the two groups. In addition, there is an effort to extend the authority of coastal natural resources management having been conducted by Pokmaswas "Kejung Samudra", which has been managing mangrove forests in Prigi Beach, which will also manage coral reef resources in the area.

Table 1 - Dimensions and specification of materials for artificial coral reefs made by the community

\begin{tabular}{|c|c|c|c|c|c|}
\hline Number & Materials & Volume & Quantity & Total & Information \\
\hline 1 & Concrete & $(0,08 \times 0,08,0,08) \mathrm{cm} \times 12$ & 25 & $1,55 \mathrm{~m}^{3}$ & \\
\hline 2 & Graffle & $0,85 \times 1,55$ & 25 & $1,32 \mathrm{~m}^{3}$ & $1,5 \mathrm{~m}^{3}$ \\
\hline 3 & Sand & $0,60 \times 1,55$ & 25 & $0,95 \mathrm{~m}^{3}$ & $1,0 \mathrm{~m}^{3}$ \\
\hline 4 & Cement & $8,5 \times 1,55$ & 25 & 13,175 sacks & 14 sacks @ $40 \mathrm{~kg}$ \\
\hline 5 & Iron $(\Theta 8 \mathrm{~cm}$ pure $)$ & Bars & 25 & 25 bars & \\
\hline 6 & Wire & & & $5 \mathrm{~kg}$ & \\
\hline 7 & Nails & & & On site conditional & \\
\hline 8 & Formwork & & \multicolumn{2}{c|}{} \\
\hline
\end{tabular}

At the Cross-Sector Integration Meeting of Potential Management of Coastal Villages organized by the Department of Marine and Fisheries of East Java Province, held on 26-27 October 2017 in Ponorogo, Chief Executive Officer of IbM as the keynote speaker met with Head of Pokmaswas Ngrembeng, which has been specifically managing the coral reefs in Prigi Gulf. Therefore, the coral reefs in Prigi Beach in particular are managed by Pokmaswas Ngrembeng at Karanggongso Village in cooperation with Damas residents.

The process of putting (by drowning) the artificial coral reefs at the determined location in Ngrumpukan (Damas Beach) was carried out with the following stages:

The artificial reefs that have been ready to be drowned are transported by two people manually to the seashore.

The artificial reefs were transported by boat with four pieces for one route. The process of transporting was executed by three fishermen, including lifting the reefs from the beach to the top of the boat, transporting to the location and lowering (sinking) the artificial reefs to the bottom of the water.

The process of putting the artificial coral reefs was executed in two stages dated on: September $17^{\text {th }}, 2017$ with the total of 15 artificial reefs; October $14^{\text {th }}, 2017$ with the total of 11 artificial reefs.

There were 26 artificial coral reefs in total drowned to bottow of the water in Damas, near Pancer Ngrumpukan area.

Economic and Ecological Value of Artificial Coral Reefs. Assuming the average size of the artificial coral reefs of $0.36 \mathrm{~m}^{2}$ per item, and there were 26 items drowned to the sea, the growing area of the artificial coral reefs would be around $9 \mathrm{~m}^{2}$. In addition to the Damas Beach, the coral reefs in this area have become potential ecosystems producing direct benefits in the form of ornamental fish production, with the indirect benefits as the habitat for fishes, coastal protection and carbon sinks.

The artificial coral reefs drowned to the sea, as it was assumed would be in good conditions as stated in the studies by Asadi and Anthon (2017) that there is $13 \mathrm{Ha}$ coral reef ecosystem in Bangsring area, and as it is calculated by using effect on production method, it may generate IDR $6,145,468,416$ per year. If there are $9 \mathrm{~m}^{2}$ of coral reef ecosystem, and there would be IDR $47,272.83$ per $\mathrm{m}^{2}$, the calculated benefits from the area namely fishing activity would be around IDR 425,455.47 per year.

The calculation of of indirect benefits such as for fish habitat using replacement cost method based on research by Asadi and Anthon (2017) yields IDR 306.64 per $\mathrm{m}^{2}$. If there 
are 26 coral reefs with the width of $9 \mathrm{~m}^{2}$, then the value of the indirect benefit as a living fish habitat of IDR 2,759.76 per year.

The existence $9 \mathrm{~m}^{2}$ of the artificial coral reefs drowned in the sea, it may break the $8.3 \mathrm{~m}^{1}$ wave length. By using replacement cost method in relation to water breaker according to Maharmingnastiti, et al (2015) worthing IDR 500,000 per $\mathrm{m}^{1}$ per year, so that the artificial coral reefs planting in this area would generate wave breaker value of IDR $4,150,000$ per year.

Coral reefs have other function as to sink carbon. In Maharmingnastiti, et al (2015), it was described that the value of primary coral reef productivity of $2.5 \mathrm{~kg} / \mathrm{m}^{2}$ annually, while the carbon absorption value of IDR 94,620 per ton. With the width of the artificial coral reefs is $9 \mathrm{~m}^{2}$, so the carbon absorption value would be IDR 2,128.95 per year.

Total Assummed Economical Value. The impacts of the artificial reef planting activities, based on the assumption of ecological and economic benefits, result in a value of IDR $4,580,344.18$ per year. This value is the sum of the value of both direct benefits of ornamental fish production and indirect benefits of living fish habitat and carbon sink.

\section{CONCLUSION AND SUGGESTIONS}

The negotiation process with local people in Damas Village was conducted by several steps with some approaches. The first was to negotiate with the formal leader Head of Karanggandu Village, informal leader "Mbah Demang" as former Head of Karanggandu Village, who is also the Head of Community Council of Forest Village "Argo Lestari". The second step was to conduct negotiations with the community represented by the Head of Pokmaswas "Jangkar Bahari" and Head of cultivating group "Udang Jaya II" which utilizes the fishery resources in Damas Beach area, especially those related to the coral reefs.

The smoothness of the negotiation process was also supported by the art group "Turangga Yaksa", where the location of the art house is in Damas. In addition, the representatives of Damas residents are involved in this activity. This group has a high social capital in terms of networking or networking.

The description and specification of the artificial coral reefs have been agreed upon the community and the executors of the planting activities, including the mechanism of transporting the artificial coral reefs to the determined location of the sea in Prigi Gulf (Damas Beach).

It is assumed that the total value of ecological and economic benefits is IDR $4,580,344.18$ per year.

Regarding the management of coral reefs in Damas Beach, it is better for the Village Government of Karanggandu to collaborate with Pokmaswas Ngrembeng that is legally performing coral reef management in Prigi Gulf. The management should involve Pokmaswas "Jangkar Bahari" and "Udang Jaya II" Group, which have been directly involved in producing and drowning the artificial coral reefs in Damas Beach.

The discussion of Village Regulation Number 04 of 2009 on Coastal Zoning of Karanggandu Village by Village Government of Karanggandu should involve relevant institutions related to coastal resources management in Prigi Gulf, for example Pokmaswas Kejung Samudra in Karanggandu Village, Pokmaswas Ngrembeng Raya in Tasikmadu Village, and Community Council of Forest Village in Karanggandu Village, Prigi Village and Tasikmadu Village.

\section{REFERENCES}

1. Asadi M.A. and Anthon A. 2017. Economic Valuation of Coral Reefs Ecosystem of Bangsring, Banyuwangi, Indonesia. ECSOFiM: Economic and Social of Fisheries and Marine Journal. Vol 4 (2): pp. 144-152.

2. COFISH Project, 2003. Reaching for the Future. Planeta Komunikatama. Jakarta.

3. Faculty of Fishery and Marine Sciences, Managing Coastal Area. University of Brawijaya. 
4. Maharmingnastiti W., Suradi W.S. \& Dian W. 2015. Valuasi Ekonomi Ekosistem Terumbu Karang Di Perairan Karang Kelop Kabupaten Kendal. Diponegoro Journal Of MAQUARES, Volume 4, Number 3, 2015, pp. 188-194

5. Village Regulation (Perdes) №4 of 2009 on Coastal Area Zoning in Karanggandu Village.

6. Purwanti P., Susilo, E., \& Indrayani, I. 2015. Pengembangan Model Pengelolaan Agroforestry Mangrove Di Kabupaten Trenggalek; Pendekatan Kelembagaan dan Ekonomi Rumah Tangga. Penelitian Unggulan Perguruan Tinggi Universitas Brawijaya.

7. Supriadi, Dedi. 2016. Pengembangan Habitat Buatan Berbasis Kearifan Lokal Dedi-Dedi. Pemerintah Kota Cirebon. Dinas Kelautan, Perikanan, Peternakan dan Pertanian.

8. Susilo, E., Hidayat, K., Syafa'at, R., Musa, M. dan Purwanti, P. 2008. Daya Adaptasi dan Jaminan Sosial Masyarakat dalam Rangka Mencapai Ketahanan Pangan Domestik (Dinamika Kelembagaan Lokal Pengelola Sumberdaya Perikanan Kawasan Pesisir) Laporan Penelitian IRD. Kementerian Negara Riset dan Teknologi Republik Indonesia

9. Susilo, E., Indrayani, I., dan Setijawati, D. 2013. Kajian Pengembangan Pengelolaan Agroforestry Mangrove Melalui Penguatan Ekonomi Rumahtangga dan Kelembagaan Pengelolaannya di Kawasan Teluk Prigi Kabupaten Trenggalek. Penelitian Unggulan Perguruan Tinggi Universitas Brawijaya. 